\title{
Evaluation of Mine Productivity and Economics by Effective Blast Instrumentation-A Techno Economic Proposition
}

\author{
Ajay Kumar Jha \\ Blasting Cell, PAD Division, Central Mine Planning and Design Institute (Coal India Limited), Ranchi 834008, India
}

\begin{abstract}
Coal is the mainstay of power generation in India. The manifold increase in demand for coal puts a huge pressure on augmenting production, primarily from opencast mines. The increase in production necessitates heavy blasting in overburden and coal benches of opencast mines which poses numerous challenges in carrying out blasting operation techno-economically. Presently, the consumption of industrial explosives and accessories in Coal India has touched a whopping figure of 350 million USD per annum. The present paper discusses some of key challenges faced in various mines of coal in India during blasting where blast instrumentation may contribute to the mine productivity and economics significantly. Blast Instrumentation at mine level will prove to a harbinger for practicing blasting engineers. The blast instrumentation at Sonepur Bazari project resulted in direct savings in explosives cost by $29.5 \%$. The use of well characterized explosives obtained by using MASW (multi channel analysis of surface waves) technique at Umrer project of Coal India Limited resulted in improvement in fragment size by $12.76 \%$. It may be concluded with high degree of confidence that blast instrumentation at mine level will influence the mine productivity and economics.
\end{abstract}

Key words: Blast instrumentation, blast simulation, mine productivity, fragmentation.

\section{Introduction}

Coal shall remain India's most important energy sources till 2031-2032 and possibly beyond. Coal dominates the energy mix in India, contributing to major share of the total primary energy production. Coal is a crucial and enduring element in a modern, balanced energy portfolio, providing a bridge to the future as an important low cost and secure energy solution to sustainability challenges. The manifold increase in demand for coal puts a huge pressure on augmenting production primarily from opencast mines as well as from underground mines [1-3]. The need of carrying out heavy blasting in overburden and coal benches of opencast mines requires blast instrumentation at mine level. The blast performance is significantly influenced by use of proper

Corresponding author: Ajay Kumar Jha, Ph.D., research field: rock blasting in mines and construction. E-mail: ajayk_jha_in@yahoo.com. instrumentation. The present paper discusses the case study carried at Umrer project and Sonepur Bazari project of Coal India Limited using advanced blast instrumentation and their influence on the mine productivity and economics.

\section{Materials and Methods}

Sonepur Bazari project of Eastern Coalfields Limited is located in the eastern part of Raniganj Coalfields in India. It is well connected by rails and roads. The Raniganj railway station on Howrah-Delhi line is about $20 \mathrm{~km}$ from the project. The Grand Trunk Road passes at $14 \mathrm{~km}$ west of the project. Four coal seams, viz., R-IV, R-V, R-VI and R-VII are mainly exposed in the mine. Presently, seams R-V and R-VI are being extracted by opencast method of mining. The mine was producing about $4 \mathrm{Mt}$ of coal and removal of overburden was about 15 million cubic meters during 2010-2011. The average stripping ratio of the mine is $4.63 \mathrm{~m}^{3} / \mathrm{t}$ coal produced. The total reserve of the project 


\section{Evaluation of Mine Productivity and Economics by Effective Blast Instrumentation-A Techno Economic Proposition}

is 188.26 million $t$. The overview of the Sonepur Bazari project is shown in Fig. 1.

\subsection{Influence of Scattering/Delay Timings on Vibration and Fragmentation}

Precise surface and down-the-hole delay timing affects explosives energy utilisation in terms of blast results, i.e., optimum fragmentation, looseness of muck pile, and favourable muck pile angle. The detonator timing do not only have influence upon the fragmentation but also upon other factors, viz., displacement of rock and swellings of rock, over break and intensity of vibration and overpressure. It is technically desirable to use precise detonators with accurate delay timings to achieve desired blast results in terms of improved fragmentation, lower level of vibration and air overpressure. Presently, scattering in initiation systems is a matter of serious concern to the mine operators as the blast performance is getting affected adversely. Delay timing is primarily provided using delay element made up of pyrotechnic composition placed between the ignition system and the primer charge. Initiation system made with pyrotechnic delay compositions has inherent scattering in their delay timings. In order to understand the effect of detonator timing and delay sequences on blast vibration, the field experimentation was carried out at Sonepur Bazari project, CIL and actual blast results were compared with the simulated blast results obtained by using simulation techniques. The simulation software named 2D Bench of JKSimblast, Australia, has been used for obtaining the simulated blast results.

\section{Results and Discussion}

3.1 Actual and Simulated Ground Vibration due to Scattering at Sonepur Bazari, CIL

The drilling and blasting parameters practiced at dragline bench of Sonepur Bazari project is shown in Table 1. The plan showing blast design layout along with the initiation sequence and output of simulated blast design obtained by using the software 2D, Bench (JKSimblast) is shown in Fig. 2. The simulated detonation timing contours along with the number of decks detonated vs. detonation time is shown in Fig. 3.

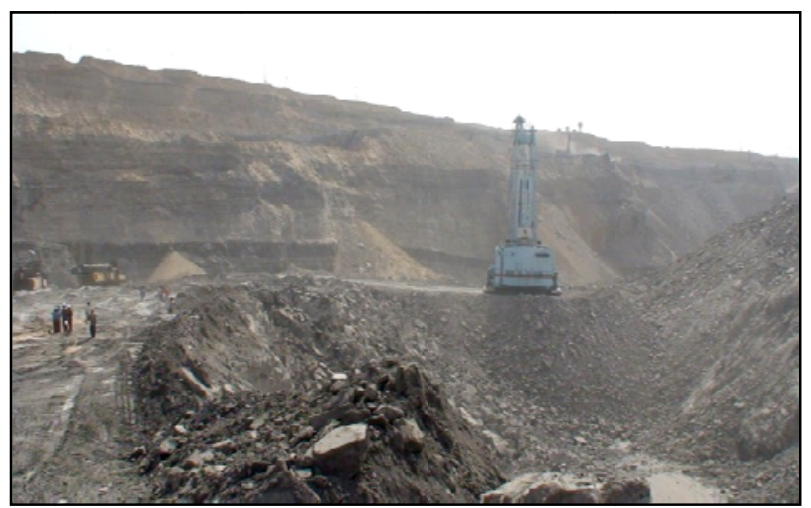

Fig. 1 Overview of Sonepur Bazari project.

Table 1 Drilling and blasting parameters practiced at dragline bench of Sonepur Bazari project.

\begin{tabular}{llll}
\hline Sl. No. & Particulars & Existing pattern & Modified pattern \\
\hline 1 & Drill diameter $(\mathrm{mm})$ & 270 & 270 \\
2 & Average bench height $(\mathrm{m})$ & 28 & 28 \\
3 & Burden $(\mathrm{m})$ & 7.5 & 8.5 \\
4 & Spacing $(\mathrm{m})$ & 8.5 & 9.5 \\
5 & No. of rows & 5 & 5 \\
6 & Holes per row & 15 & 15 \\
7 & Pattern of holes & Staggered & Staggered \\
8 & Bottom charge $(\mathrm{kg})$ & 600 & 600 \\
9 & Top charge $(\mathrm{kg})$ & 325 & 300 \\
10 & Linear density $(\mathrm{kg} / \mathrm{m})$ & 52 & 50 \\
11 & Volume per blast $\left(\mathrm{m}^{3}\right)$ & 133,875 & 169,575 \\
12 & Total explosive quantity $(\mathrm{kg})$ & 69,375 & 67,500 \\
13 & Powder factor $\left(\mathrm{m}^{3} / \mathrm{kg}\right)$ & 1.93 & 2.50 \\
\hline
\end{tabular}



Proposition

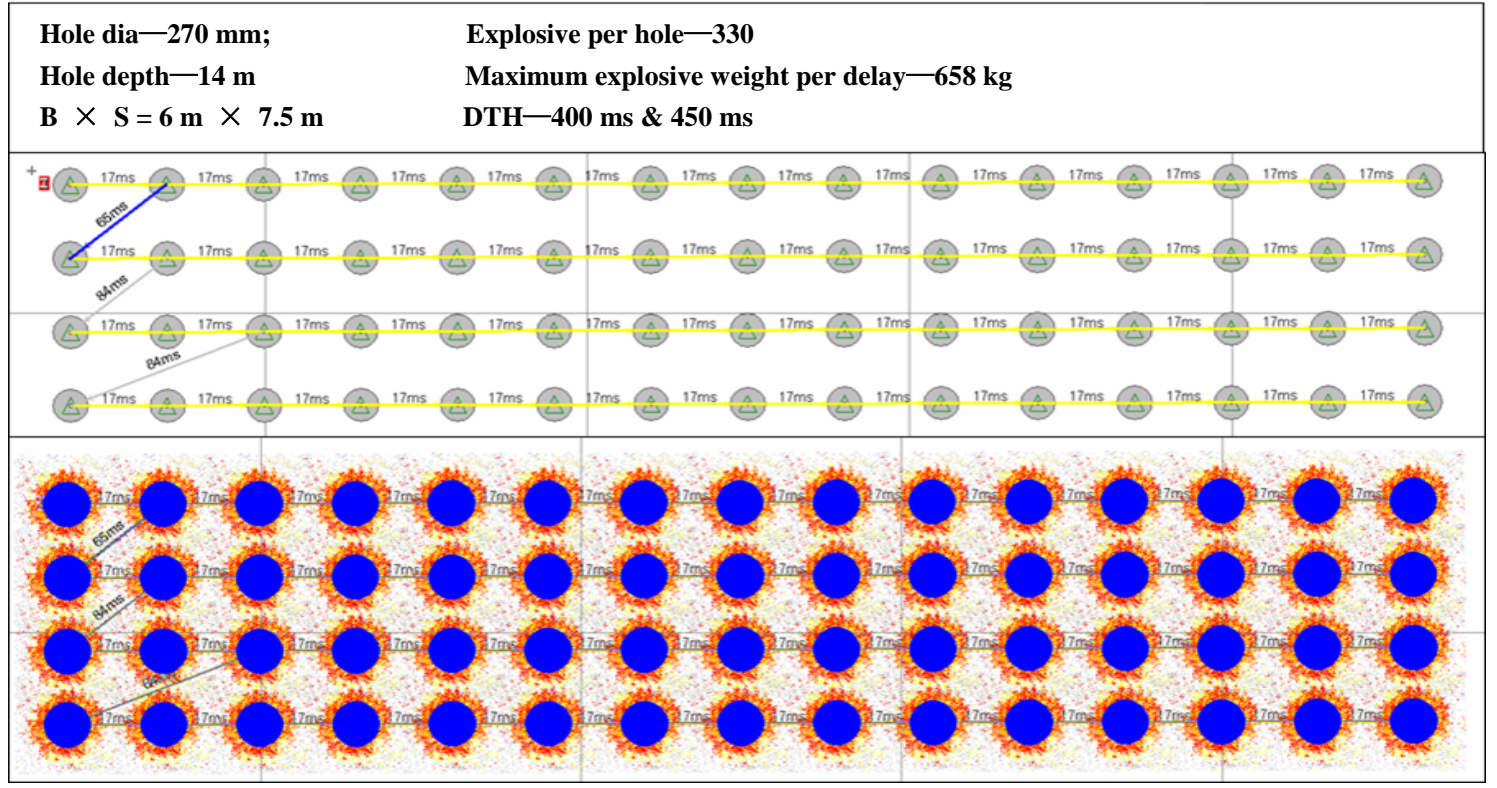

Fig. 2 Plan showing blast design layout along with the initiation sequence and simulated blast result.

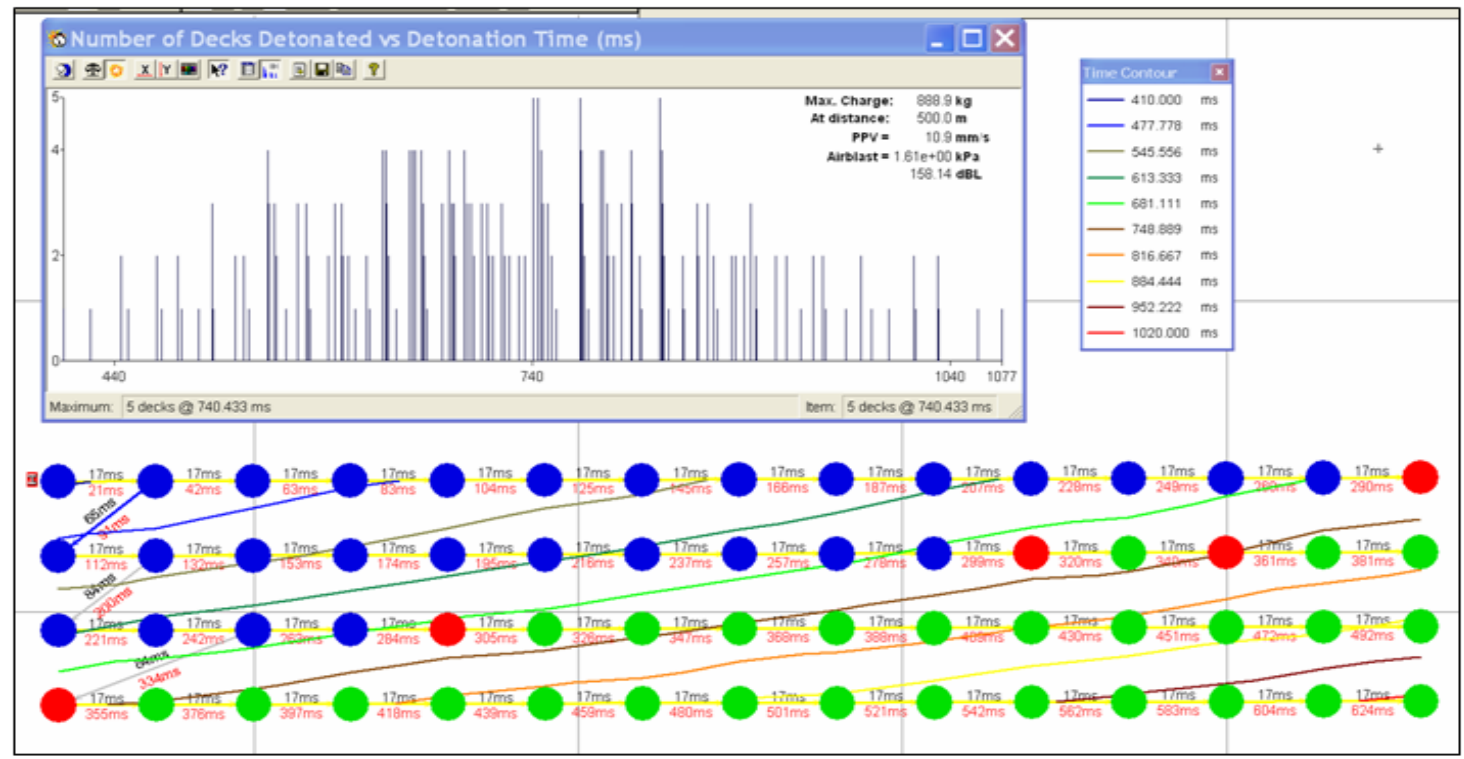

Fig. 3 Detonation timing contours along with the number of decks detonated vs. detonation time.

Ground vibration data were recorded at Sonepur Bazari project by using multi channel seismograph, i.e., Minimate Plus manufactured by Instantel, Canada. The changes in explosives charge weight per delay $\left(Q_{\max }\right)$ between the designed $Q_{\max }$ and actual $Q_{\max }$ due to scattering in delay detonators used during blasting for the blast design shown in Fig. 2, at a distance of $500 \mathrm{~m}$ was simulated by $2 \mathrm{D}$ Bench software (JKSimblast) using Monte Carlo simulation and is tabulated in Table 2. Fifteen experiments were simulated with scattering percentage varying from 1 to 15 using Monte Carlo simulation algorithm in $2 \mathrm{D}$ Bench software. It is evident from the results that scattering in the delay detonator has affected the actual explosive charge per delay which will result into increase in blast induced ground vibration.

\subsection{Fragmentation Assessment by WipFrag}

The dragline bench of Umrer project, CIL, as facing the problem of low productivity as a result of handling 
Table 2 Changes in explosives charge weight per delay due to scattering in detonator timing at Sonepur Bazari project.

\begin{tabular}{llll}
\hline Designed experiment number & \% of scattering & $Q_{\max }$ (with designed delay) & $Q_{\max }$ (with actual delay) \\
\hline 1 & 1 & 658 & 889 \\
2 & 2 & 658 & 1,021 \\
3 & 3 & 658 & 1,021 \\
4 & 4 & 658 & 889 \\
5 & 5 & 658 & 1,350 \\
6 & 6 & 658 & 1,152 \\
7 & 7 & 658 & 1,021 \\
8 & 8 & 658 & 988 \\
9 & 9 & 658 & 1,021 \\
10 & 10 & 658 & 1,218 \\
11 & 11 & 658 & 1,251 \\
12 & 12 & 658 & 1,119 \\
13 & 13 & 658 & 1,218 \\
14 & 14 & 658 & 922 \\
15 & 14 & 658 & 1,218 \\
\hline
\end{tabular}

more oversized boulders by the dragline bucket, tight muck pile and adverse muck pile profile. The bucket size of the dragline was $10 \mathrm{~m}^{3}$. Originally, there was no blast instrumentation at Dragline bench and the drilling and blasting parameters were optimised by trial and error method by conducting blasting experiments, using experience of blasting engineers. The drilling and blasting parameters practiced at Umrer project, before using any blast instrumentation methodology is mentioned in Table 1.

The burden relief rate of $3 \mathrm{~ms} / \mathrm{m}$ was used at the mine on the basis of past experiences without using any scientific study using high speed camera. The fragmentation assessment was carried out by adopting digital image analysis technique and using the granularity software, i.e., WipFrag. The graph showing the fragment size distribution and percentage of oversized boulders was $12.76 \%$ and is shown in Fig. 4. It is evident that poor productivity of Dragline was due to significant percentage of oversized boulders.

\subsection{Fragmentation Improvement by Blast Instrumentation}

In order to improve the blast fragmentation at the mine, 1,000 frames per second high speed camera manufactured by MREL, Canada was used and coloured markers were suspended freely on the blast face to calculate the optimum burden relief rate. The captured photographs were analysed by using the ProAnalyst software. It was inferred that a minimum of $10 \mathrm{~ms} / \mathrm{m}$ is needed at the dragline bench of Umrer project for proper onset of movement for getting the optimum fragmentation. After knowing the optimum burden relief rate, intra deck, inter hole and inter row delay interval was calculated. The modified drilling and blasting parameters after suitable blast instrumentation at Umrer project is mentioned in Table 1.

By adopting the modified drilling and blasting parameters, the percentage of oversized boulders was brought to $0 \%$, which led to improvement in mine productivity. In order to select the suitable explosives techno-economically, geophysical technique such as seismic survey method was to characterize the rock mass using MASW (multi channel analysis of surface waves) system (Coal S\&T Report MT/146). The MASW system with its various components is shown in Fig. 5. The layer wise VOD (confined velocity of detonation) at various depths of the rock mass for achieving optimal explosives energy utilisation is shown in Fig. 6. Based on the results of MASW, emulsion explosives having VOD of $5,500 \mathrm{~m} / \mathrm{s}$ was used at the dragline bench as against the normal practice of using emulsion explosives having VOD of 4,500 m/s. The inter hole delay and inter row delay was computed from the burden relief rate obtained by using high 


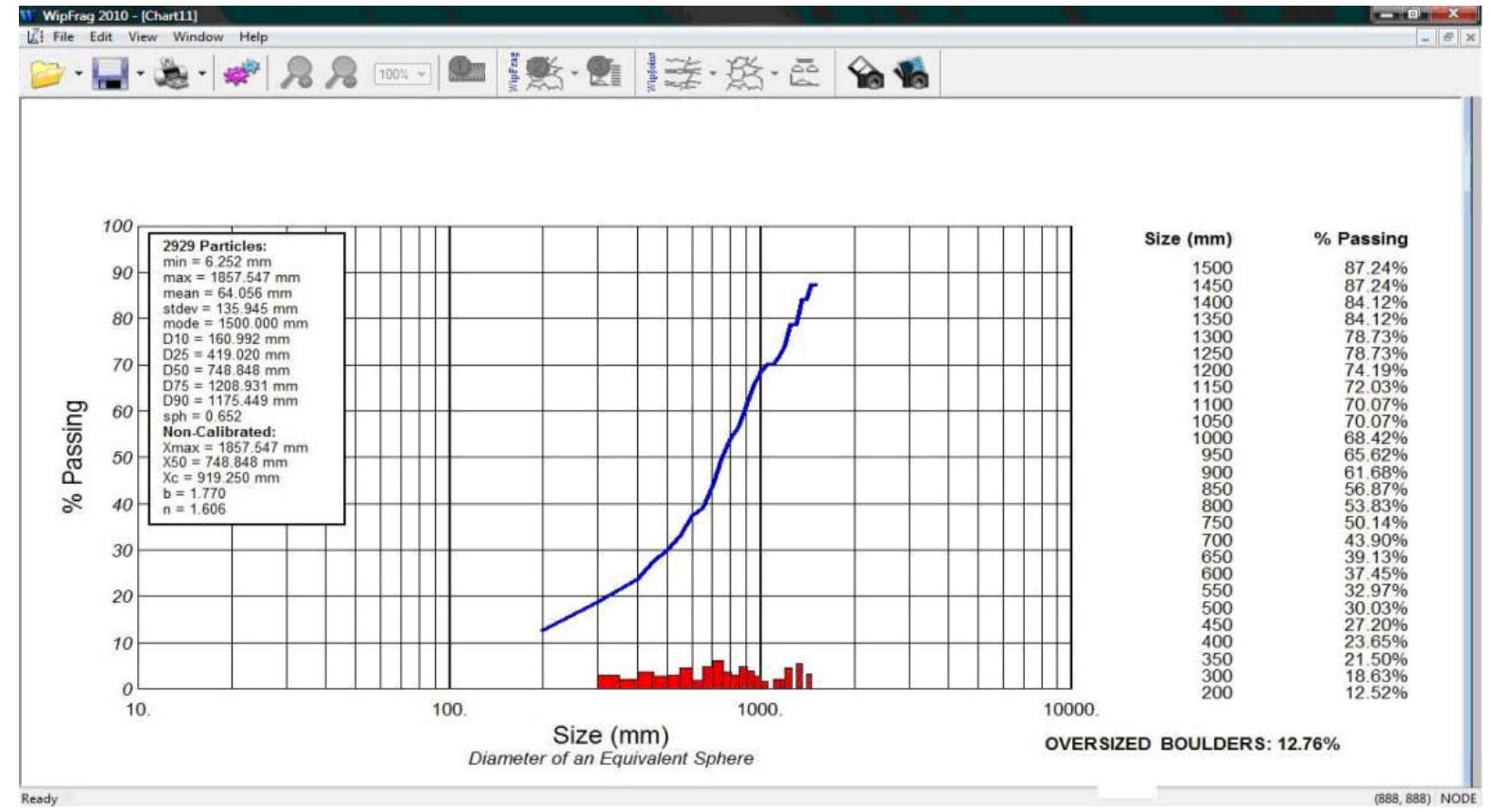

Fig. 4 Fragmentation results by using Wipfrag software at Umrer project.

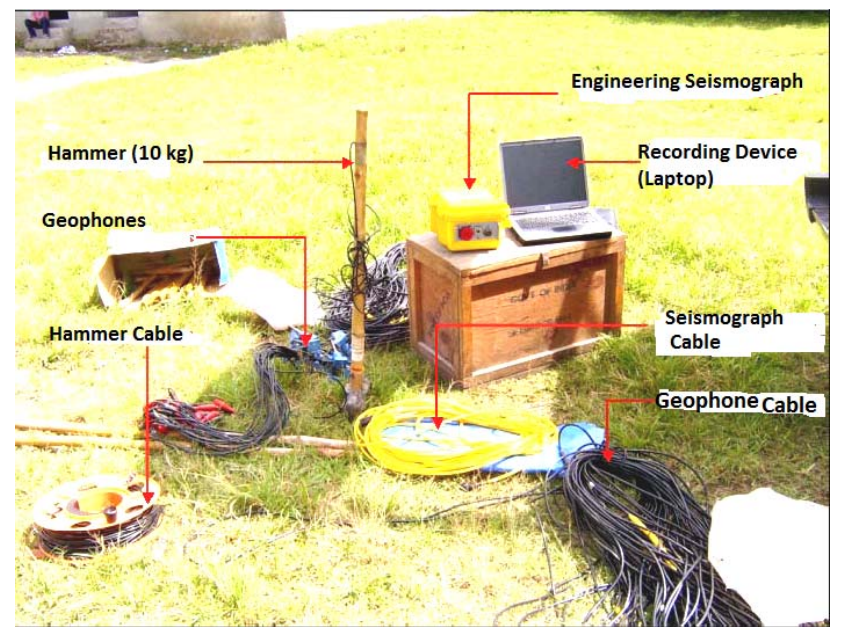

Fig. 5 Various components of the MASW system.

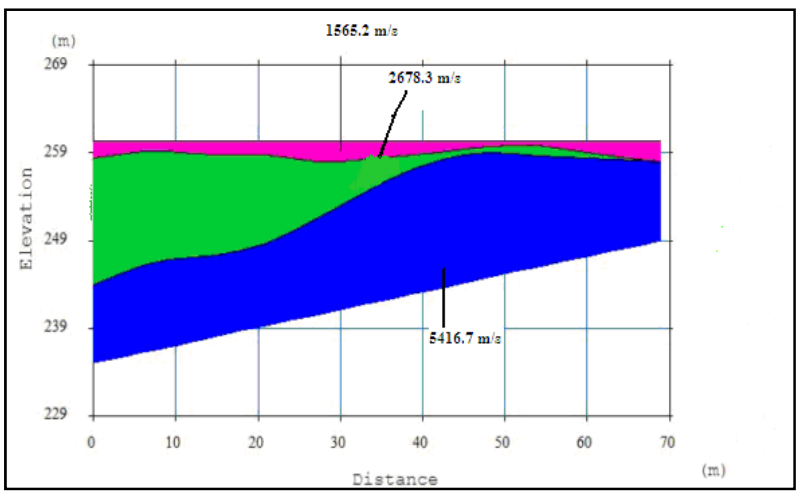

Fig. 6 VOD of explosives profile of major cluster of layers of overburden bench at Umrer project. speed camera and ProAnalyst software. The average toe burden was obtained by using the instrument Burden finder manufactured by MDL, UK.

The fragmentation assessment, after using necessary blast instrumentation was carried out by adopting Digital Image Analysis technique and using the granularity software, i.e., WipFrag, is shown in Fig. 7. It was observed that the percentage of oversized boulders got reduced to zero and there was an increase in powder factor resulting into saving of explosives cost by $28 \%$.

\subsection{Minimum Deck Thickness between Deck Charges}

Decking is a technique that enables the blaster to divide the explosives in a blast hole into two or more locations. This is accomplished by loading an inert material, such as crushed stone or drill cuttings between the explosives charges. Decking is used primarily for the following purposes:

(1) To give confinement of explosion gases where a soft seam or void is encountered;

(2) To give a better energy utilization;

(3) To cope up with vibration constraints and reduce the explosives weight per delay. 


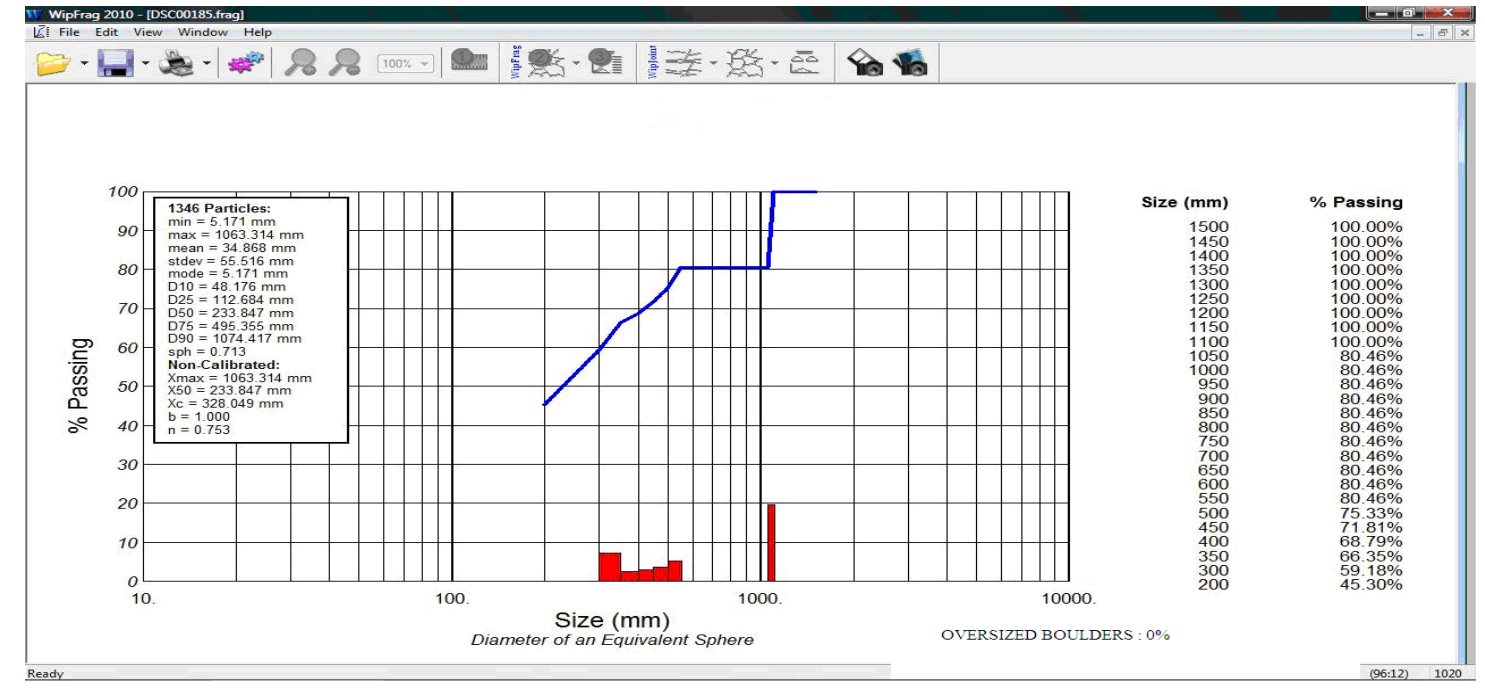

Fig. 7 Fragmentation results by using WipFrag software at Umrer project.

The reason for minimal deck thickness is to ensure that sympathetic detonation and/or cross propagation between charges does not occur. The minimal deck thickness will also ensure that there is no pressure desensitisation of explosives in upper decks due to detonation of explosives column of lower decks or adjacent boreholes arising out of pressurisation of nearby detonated boreholes. The pressure desensitisation in receptor explosive column may be classified as follows:

(1) sympathetically initiate the detonator (i.e., instantaneous detonation);

(2) sympathetic desensitisation of upper decks;

(3) sympathetic detonation of upper deck.

Pressurise the detonator in the booster and thereby increase its firing time.

The pressurisation may result into density increase or fall of sensitivity of explosives column in adjacent boreholes

In opencast blasting, the minimum bench height necessary for effective decked charges should be such as to give the ratio of $H / D>70$, where $H$ is the bench height $(\mathrm{m})$ and $D$ is the drill diameter ( $\mathrm{mm}$ ) [2-7]. In order to understand the role of decking on pressure desensitisation in a borehole deck, thickness was varied from $4 D$ to $12 D$ between the upper and bottom explosives charge columns, where $D$ shows the borehole diameter $(\mathrm{mm})$. The in-the-hole VOD of the explosives column in top deck and bottom deck explosives column was measured by Datatrap-II manufactured by MREL with the help of VOD probe cable of high resistivity, i.e., $10.8 \Omega / \mathrm{m}$.

When the deck thickness was not optimum, detonation of bottom explosives column affected the top explosives column as recorded by DataTrap-II, i.e., top deck got detonated prior to the designed time delay between top and bottom explosives columns due to pressurisation. When the deck thickness was optimum, the top and bottom decks were monitored as independent events. The in-the-hole VOD of explosives plot vividly shows the actual time delay between the decks along with the in-the-hole VOD of explosives values of top and bottom explosives columns. Fig. 8 shows the typical in-the-hole VOD of explosives plots recorded in both the explosives columns in the blast hole (bottom charge and top charge) at Umrer project.

Similarly, the recorded in-the-hole VOD of explosives at Umrer project for bottom and top decks are presented in Table 3. In some cases, the top column of the explosives in the blast hole got affected due to bottom explosives pressurisation. The designed time interval between the detonators in bottom and top explosives column and the length of the deck between 


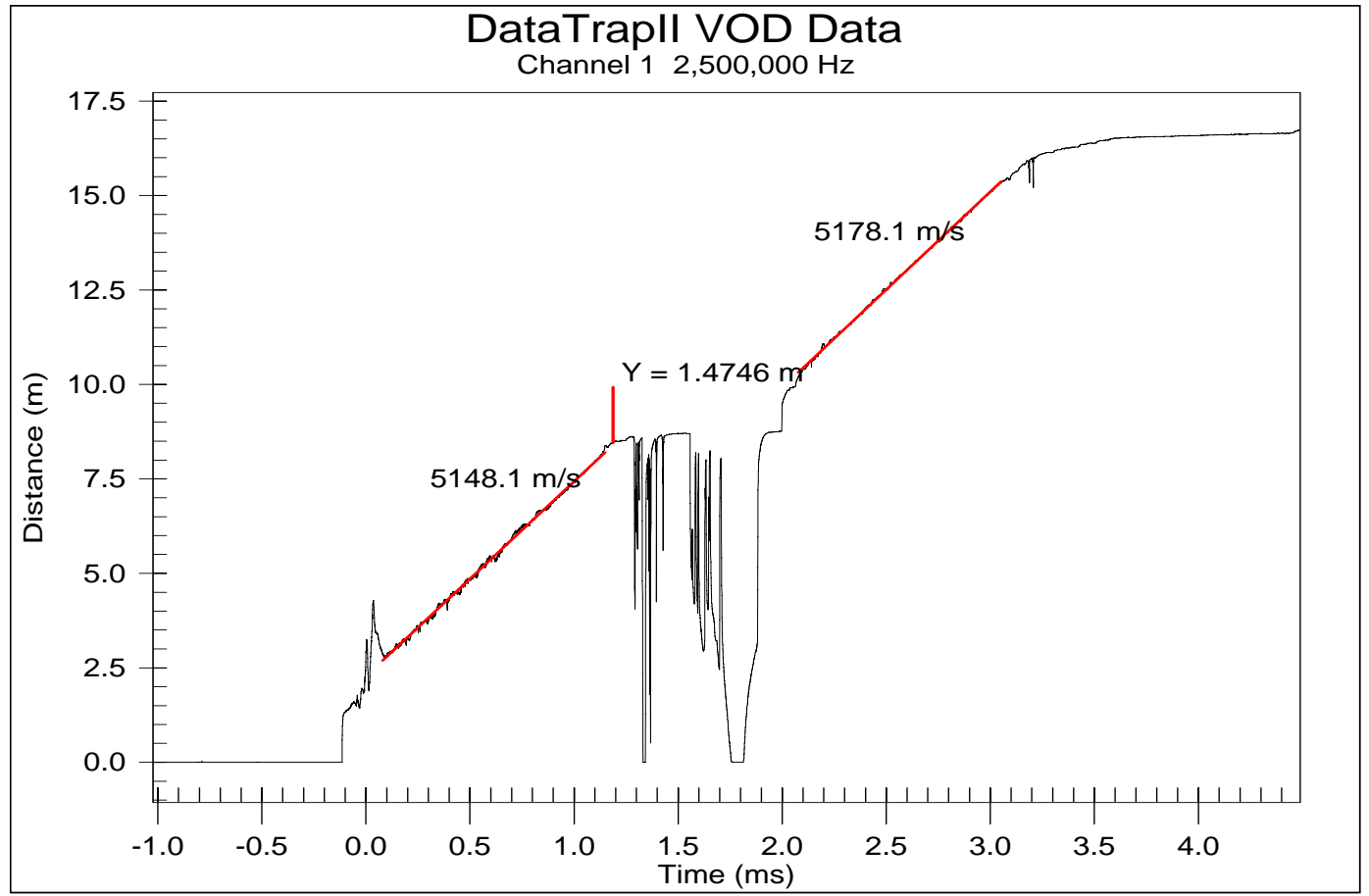

Fig. 8 In-the-hole VOD of explosives plot recorded at Umrer project.

Table 3 Designed and actual time gap between top and bottom explosives column along with measured in-the-hole VOD of explosives at Umrer project.

\begin{tabular}{|c|c|c|c|c|c|c|c|}
\hline Sl. No. & $\begin{array}{l}\text { Deck } \\
\text { thickness in } \\
\text { terms of } \\
\text { drill } \\
\text { diameter }\end{array}$ & $\begin{array}{l}\text { Hole-dia-meter } \\
(\mathrm{mm})\end{array}$ & $\begin{array}{l}\text { In-the-hole } \\
\text { VOD } \\
\text { of bottom } \\
\text { explosives } \\
\text { column }(\mathrm{m} / \mathrm{s})\end{array}$ & $\begin{array}{l}\text { In-the-hole VOD } \\
\text { of top explosives } \\
\text { column }(\mathrm{m} / \mathrm{s})\end{array}$ & $\begin{array}{l}\text { Actual } \\
\text { time gap between } \\
\text { top and bottom } \\
\text { explosives } \\
\text { column (ms) }\end{array}$ & $\begin{array}{l}\text { Designed } \\
\text { Time Gap } \\
\text { between } \\
\text { top and bottom } \\
\text { explosives } \\
\text { column (ms) }\end{array}$ & Remark \\
\hline UMR-1 & $4 \mathrm{D}$ & 270 & $5,148.1$ & $5,178.1$ & 2.2 & 50 & Top column got affected \\
\hline UMR-2 & $4 \mathrm{D}$ & 270 & $4,820.5$ & $4,825.1$ & 2.1 & 50 & Top charge got affected \\
\hline UMR-3 & $6 \mathrm{D}$ & 160 & 4,882 & 4,840 & 3.1 & 25 & Top charge got affected \\
\hline UMR-4 & $6 \mathrm{D}$ & 160 & 5,648 & 5,438 & 3.6 & 50 & Top charge got affected \\
\hline UMR-5 & $6 \mathrm{D}$ & 250 & $4,778.8$ & 4,619 & 3.8 & 50 & Top charge got affected \\
\hline UMR-6 & $8 \mathrm{D}$ & 160 & 5,152 & 4,787 & 3.94 & 50 & Top charge got affected \\
\hline UMR-7 & $8 \mathrm{D}$ & 270 & 5,019 & 4,567 & 4.8 & 50 & Top charge got affected \\
\hline UMR-8 & $8 \mathrm{D}$ & 270 & 5,049 & 4,835 & 4.14 & 50 & Top charge got affected \\
\hline UMR-9 & $8 \mathrm{D}$ & 270 & 5,155 & 4,637 & 3.9 & 50 & Top charge got affected \\
\hline UMR-10 & $10 \mathrm{D}$ & 160 & $5,610.1$ & 5,100 & 56 & 50 & Top charge not affected \\
\hline UMR-11 & $10 \mathrm{D}$ & 270 & $5,270.7$ & 5,068 & 58 & 50 & Top charge not affected \\
\hline UMR-12 & $10 \mathrm{D}$ & 270 & 4,638 & 4,416 & 53 & 50 & Top charge not affected \\
\hline UMR-13 & $12 \mathrm{D}$ & 160 & 5,213 & 5,014 & 55 & 50 & Top charge not affected \\
\hline
\end{tabular}

two charges is also presented in the Table 3.

Based on the field experimentation, the optimal deck length between two explosive charges in the blast holes to obviate any chance of occurrences of pressure desensitization inside a borehole may be approximated to $10 D$ as shown in Fig. 9. Thus, deck length of $10 D$ may be considered as optimal deck length for Umrer project to have no likelihood of pressure desensitisation of upper deck due to detonation of bottom deck explosives charge [8]. The cast booster was positioned at a distance of $4 D$ from the floor of the blasthole. 


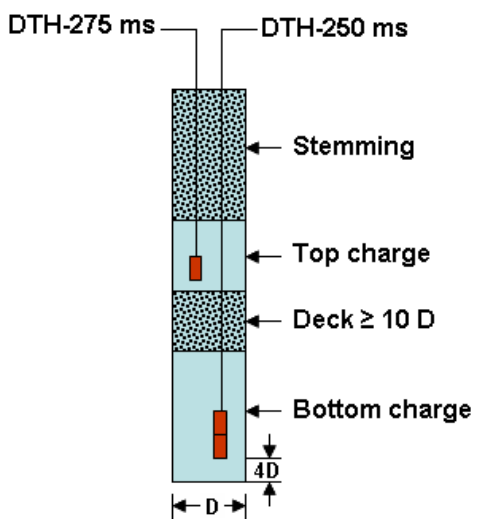

Fig. 9 Optimal deck length between explosives column in a borehole.

\section{Conclusions}

The scattering in delay detonators affects the techno economics of the blasting which has adverse impact on the mine productivity and economics. The scattering affects the blast performance significantly by worsening the overall blast performance by increased blast induced vibration and reduced fragmentation. There is significant impact of detonators timing and delay sequences on blast vibration characteristics and scattering in detonator timing influences the energy utilisation in rock fragmentation. The minimum deck thickness for mines of Coal India Limited using drill cuttings as decking materials should be $10 D$, where $D$ shows the drill diameter to have no likelihood of pressure desensitisation of upper deck due to detonation of bottom deck explosives charge. The blast instrumentation provides improved blast performance with high degree of confidence at mine level by influencing the mine productivity. It may be concluded that blast instrumentation is a key to mine productivity and economics.

\section{References}

[1] A.K. Jha, H.K. Mishra, Chopra R.K, Safety, Security \& Recent Trends in Explosives, Explo Safe Press, Nagpur, India, 2013.

[2] A.K. Debnath, A.K. Jha, Blast instrumentation-a key to mine productivity, in: Proceedings of the 23rd World Mining Congress, Montreal, Quebec, Canada, 2013, pp. 301-313.

[3] A.K. Jha, A. Biswas, IT enablement in drilling and blasting, in: Proceeding of the XXVI International Mneral Processing Congress IMPC 2012, New Delhi, India, 2012, pp. 2318-2334.

[4] C.L. Jimeno, E.L. Jimeno, F.J.A. Carcedo, Drilling and Blasting of Rocks, CRC Press, Brookfield, Rotterdam, 1995, pp. 156-157.

[5] K.W Xia, S. Huang, A.K.Jha, Dynamic tensile strength of coal, shale and sandstone using split Hopkinson pressure bar: A tool for blast and impact assessment, International Journal of Geotechnical Earthquake Engineering 7 (12) (2010) 24-37.

[6] A.K. Jha, D. Deb, N.C. Jha, Impact assessment of surface mine blasting on adjacent underground mine structures using field measurements and numerical techniques, in: J.A Sanchidrian(Ed), Rock Fragmentation by Blasting, CRC Press, Granada, Spain, 2009, pp. 571-577.

[7] A.K. Singh,A.K. Jha, A critical analysis of application of ANFO and ANFO blends in opencast coal mine blasting in India, Visfotak 6 (2011).

[8] A.K. Jha, Characterisation of Rock and Explosive Parameters for Optimal Explosives Energy Utilization in Opencast Blasting, technical report for Ministry of Coal, Government of India, India, Mar. 2010. 